\title{
Additions to the systematic of the bethylid fauna (Hymenoptera, Chrysidoidea) from Chile
}

\author{
Celso Oliveira Azevedo ${ }^{1}$
}

\begin{abstract}
Bethylopsis carinatus sp.n., and Epyris chilensis sp.n., from Chile are described and illustrated. Taxonomic data on Chilepyris herbsti Evans, Lytopsenella herbsti (Kieffer), Lytopsenella testaceicornis (Kieffer) and Pseudisobrachium erythrocephalum Evans are included. Male of Lytopsenella herbsti is recorded for the first time to genus and species.

KEY WORDS. Hymenoptera, Bethylidae, Chile
\end{abstract}

The bethylid fauna of Chile has been poorly studied. Up to now, there were only nine species of five genera known from Chile, all of them endemic, including one species from Juan Fernandez Island (Tab. I). All bethylid fauna of Chile is known from south to the Atacama desert.

The bethylid fauna of Chile is closed associated to Australian fauna. Lepidosternopsis Oglobin, 1953 is a genus exclusively from both regions with three species. Lytopsenella Kiefer, 1911 is endemic genus to Chile deeply associated to Australian Eupsenella Westwood, 1874. Both genera have the largest number of fully closed cells on the forewing of any bethylid (EvANS 1964) and are the most primitive of Bethylidae POLASzEK \& KROMBEIN (1994).

The bethylid fauna of Chile is also associated to North American fauna, but not so much as to Australian one. Examples which illustrate this case are Epyris chilensis sp.n., (see further discussion) and Apenesia chilena which is most similar to A. exilis Evans, 1963 from the southwestern United States (Evans 1967).

The present study provides descriptions of two new species, Bethylopsis carinatus sp.n. and Epyris chilensis sp.n., and new data on species variation and distribution of Chilepyris herbsti Evans, 1964, Lytopsenella herbsti (Kieffer, 1904), Lytopsenella testaceicornis (Kieffer, 1910) and Pseudisobrachium erythrocephalum Evans, 1973. Bethylopsis Fouts, 1939 and Epyris Westwood, 1832 are recorded for the first time to Chile. The male of Lytopsenella is described for the first time.

The material examined in this study was provided by American Museum of Natural History (AMNH, E. Quinter \& J. Carpenter), Canadian National Collection of Insects (CNCI, J.T. Huber), Museo Nacional de Historia Natural de Chile (MNNC, A. Camousseight), Museum of Comparative Zoology (MCZH, S. Cover \& P.D. Perkins) and Universidade Federal do Paraná (DZUP, K. Zanol).

1) Departamento de Biologia, Universidade Federal do Espirito Santo. Avenida Marechal Campos 1468, Maruípe, 29040-090 Vitória, Espirito Santo, Brazil.

E-mail: cazevedo@npd.ufes.br 
Abbreviations used mostly follow EVANS (1964): (LFW) length of forewing; (WH) maximum width of head, including eyes; (LH) length of head, measured from apical margin of clypeus to median point of vertex; (WF) minimum width of frons; (HE) maximum height of eye; (WOT) maximum width of ocellar triangle, including posterior ocelli; (OOL) shortest ocello-ocular line; (VOL) vertex-ocular line, measured in lateral view; (DAO) diameter of anterior ocellus. The nomenclature of the integument follows HARRIS (1979).

Table I. Distribution of Chilean species of Bethylidae.

\begin{tabular}{llll}
\hline \multicolumn{1}{c}{ Species } & Sex & \multicolumn{1}{c}{ Locality } & \multicolumn{1}{c}{ Reference } \\
\hline Lytopsenella herbsti & 1 female & Concepción & KIEFFER (1904) \\
Lytopsenella testaceicornis & 1 female & Vallee de Rengo & KIEFFER $(1910)$ \\
Lepidosternopsis kuschiliana & 1 female & Juan Fernandez Island & OGLOBLIN $(1953)$ \\
Chilepyris herbsti & 1 male & Baños de Cauquenes & EVANS (1964) \\
Apenesia chilena & 1 male & Pichinahuel & EVANS (1967) \\
Pseudisobrachium chilensi & 3 males & Rinconada Maipú & EVANS (1969a) \\
A. pygmaea & 1 male & Rinconada Maipú & EVANS (1969b) \\
Pseudisobrachium erythrocephalum & 2 males & Malleco & EVANS (1973) \\
Pseudisobrachium cunco & 3 males & Dalcabue & PEREZ (1981) \\
\hline
\end{tabular}

\section{Lytopsenella Kieffer, 1911}

KIEFFER (1914) proposed a key to species of Lytopsenella based on the presence and absence of hairs in the eyes, but all analyzed specimens of Lytopsenella have hairy eyes. A new key to the species of this genus is presented:

1. head subquadrate in dorsal view (Fig. 1), and large behind the eyes, VOL 0.74-1.0 X HE (Fig. 2); scutellar groove thin as a line (Fig. 1) . . . . . . testaceicornis -. head rounded in dorsal view (Figs 4, 7), and not large behind the eyes, VOL 0.44-0.6 X HE X HE (Figs 5, 8); scutellar groove thicker than above, nearly

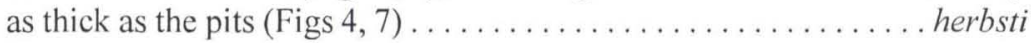

\section{Lytopsenella testaceicornis (Kieffer, 1910)}

\section{Figs 1-3}

Eupsenella testaceicornis Kieffer, 1910: 54

Lytopsenella testaceicornis; Kieffer, 1911: 203, 1914: 554. -Evans, 1964: 183. - Gordh \& Moczar, 1990: 33

This species was known only from the type. In this study three more females are analyzed. Some taxonomic data are as follow: length of body 4.17-4.33 mm; LFW 2.56-2.66 mm; head (Figs 1,2): frons coriaceous, punctures very shallow, separated by 1-2 X their diameters; mandible tetradentate (Fig. 3); clypeus with angulate median lobe, with a very high median carina; eye sparse-haired; LH 1.09-1.16 X WH; WF 0.63-0.66 X WH; eye small, WF 1.43-1.56 X HE; frontal angle of ocellar triangle right to obtuse; OOL 1.58-1.88 X WOT; head developed behind the eye top, VOL 0.74-0.92 X HE (Fig. 2); vertex slightly convex with rounded corners; temples parallel; head subquadrate; mesosoma (Fig. 1): notauli absent in the anteriorly; parapsidal furrows very weak, weaker behind; propodeal 

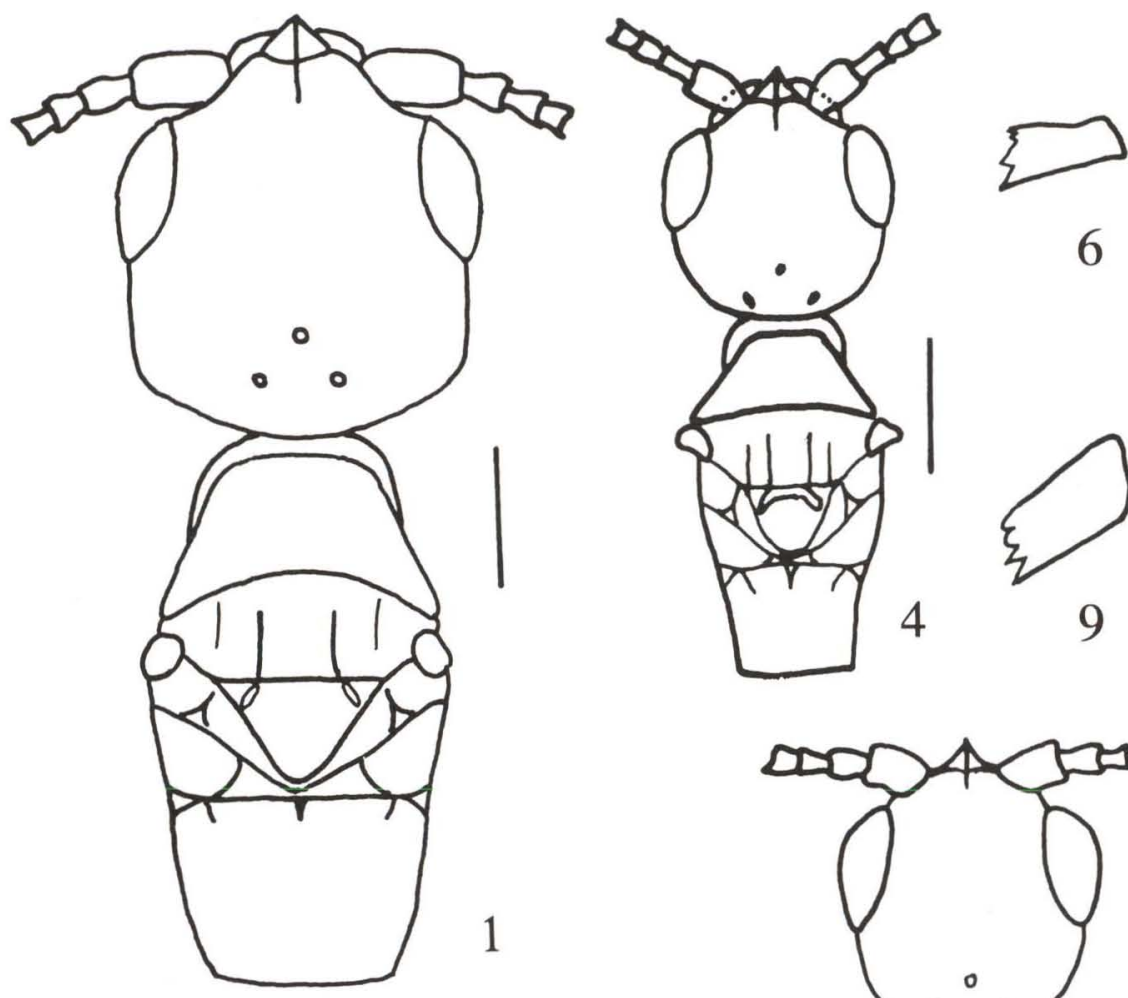

6
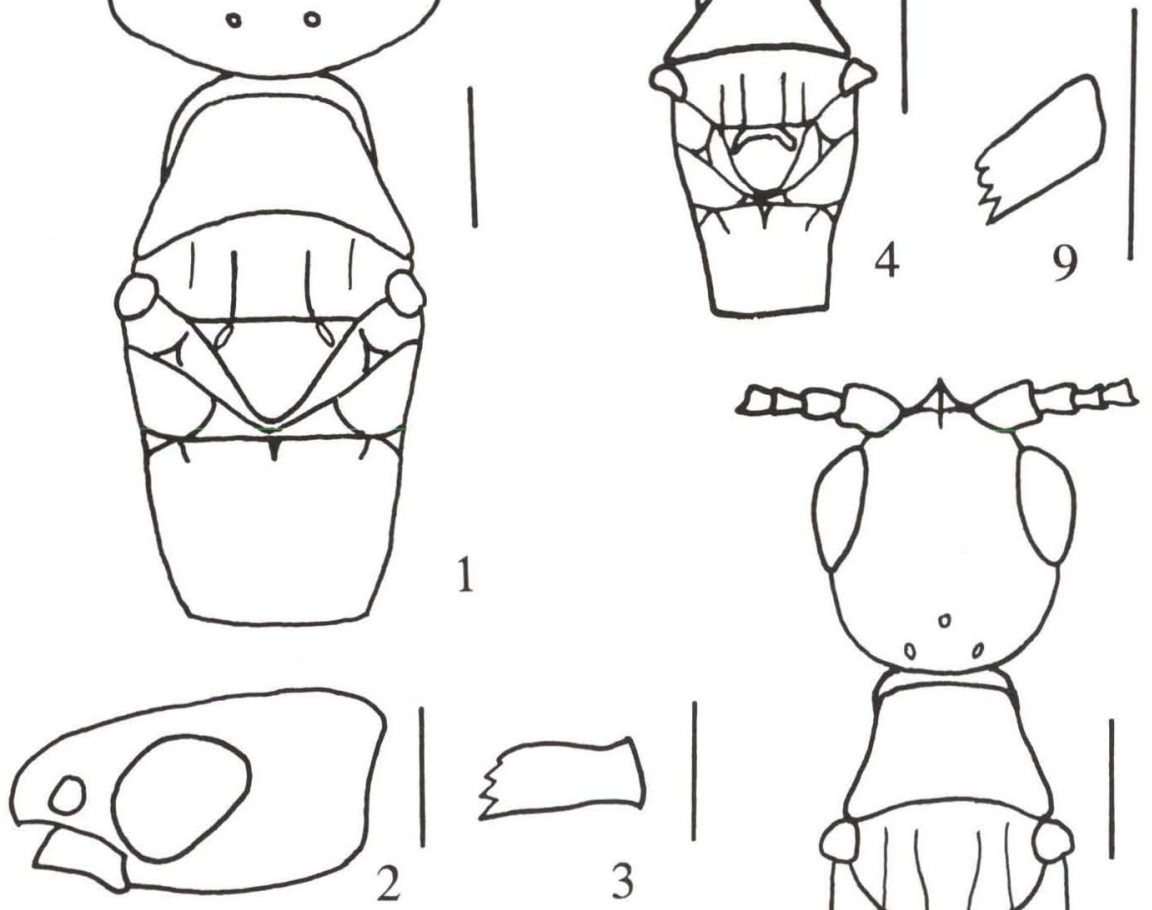

3
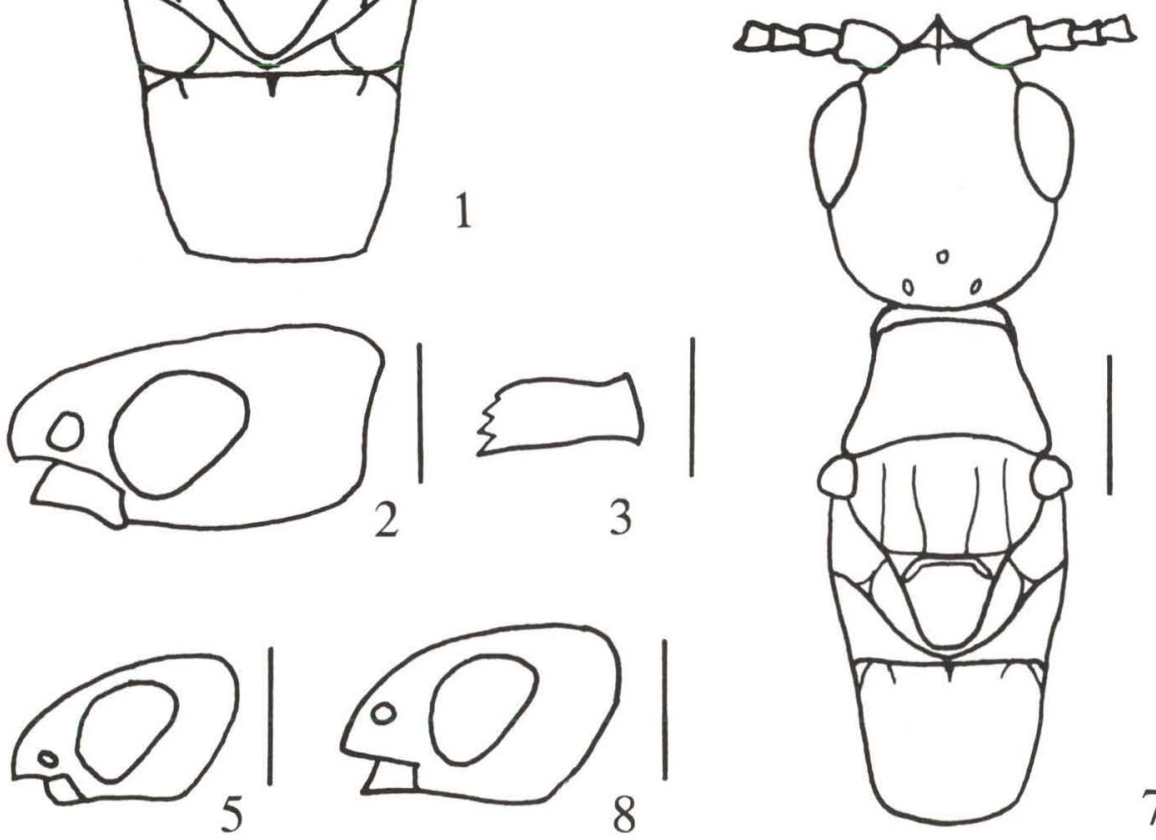

Figs 1-9. (1-3) Lytopsenella testaceicornis, female: (1) head and mesosoma, dorsal; (2) head. Lateral; (3) mandible, frontal. (4-9) L. herbsti, (4-6) female: (4) head and mesosoma, dorsal; (5) head. Lateral; (6) mandible, frontal; (7-9) male: (7) head and mesosoma, dorsal; (8) head lateral; (9) mandible, frontal. Scale bars $=0.3 \mathrm{~mm}$. 
disc $1.1 \mathrm{X}$ as wide as long, wholly alveolate, with an anterior stub of median carina and with a pair of anterior stub of discal carinae far from the median one; mesopleuron with a rounded and deep central pit, gaster polished, transversal section elliptical, slightly larger than mesosoma.

Material examined. CHILE, Arauco: Pichinahuel (Cord. Nahuebuta), 3 females, XII.1958-I.1959, L. Peña leg. (CNCI, DZUP).

\section{Lytopsenella herbsti (Kieffer, 1904)}

Figs 4-11

Eupsenella herbsti Kieffer, 1904: 142-144; 1908: 12.

Lytopsenella herbsti; Kieffer, 1911: 203, 1914: 554-555. - Evans, 1964: 181-183. - Gordh \& Moczar, 1990: 33.

This species was known only from the type. In this study 24 specimens are analyzed, some of them males, which are described below by the first time to the species and genus. This species has been the most collected Bethylidae species in Chile.

Some taxonomic data of female are as follow: length of body $2.76-3.74 \mathrm{~mm}$; LFW 1.87-2.21 mm; body black, mandible black, sometimes either with apical half castaneous or wholly castaneous; ventral side of antenna light castaneous and dorsal side dark castaneous, scape light castaneous with a basal dorsal spot darker, sometimes antenna wholly light castaneous, legs wholly castaneous, sometimes tibiae and tarsi light castaneous; head (Figs 4, 5): mandible tetradentate (Fig. 6); clypeus with angulate median lobe, with a very high median carina, arched in profile; eye short and sparse-haired; frons coriaceous, punctures shallow, separated by 0.7-2 $\mathrm{X}$ their diameters; LH 1.04-1.11 X WH; WF 0.57-0.6 X WH; eye large, WF 1.09-1.28 X HE; OOL 1.3-1.72 X WOT; head not large behind the eye top, VOL 0.41-0.48 X HE (Fig. 5); vertex slightly convex with rounded corners; temples slightly divergent anteriorly; mesosoma (Fig. 4): pronotal disc with anterior corners angulate, short, with lateral margin very convergent behind; notauli usually present only in the posterior half, but not reaching the posterior margin of mesoscutum, occasionally either short, reduced to the posterior fourth or longer, missing only in the anterior fourth; parapsidal furrows very weak, absent in the anterior third; propodeal disc about $1.5 \mathrm{X}$ as wide as long, with an anterior stub of median carina and with a pair of anterior stub of discal carinae, $2 \mathrm{X}$ longer than the median one, without other carinae, propodeum alveolate, except lateral sides coriaceous; mesopleuron with a rounded and deep central pit; gaster polished, transversal section elliptical, slightly to much longer than mesosoma.

Description. Male: length of body $2.36 \mathrm{~mm}$; LFW $1.58 \mathrm{~mm}$.

Colors. Body black; clypeus black; antenna and palpi castaneous; mandible light castaneous; legs dark castaneous, trochanters and tarsi lighter; wings hyaline, veins light castaneous, stigma darker.

Head (Figs 7, 8). Mandible tetradentate, two lower teeth larger (Fig. 9). Clypeus with an angulate median lobe, with a very high median carina arched in profile. First four antennal segments in a ratio of 12:6:5:5, segment XI 1.2 X as long 

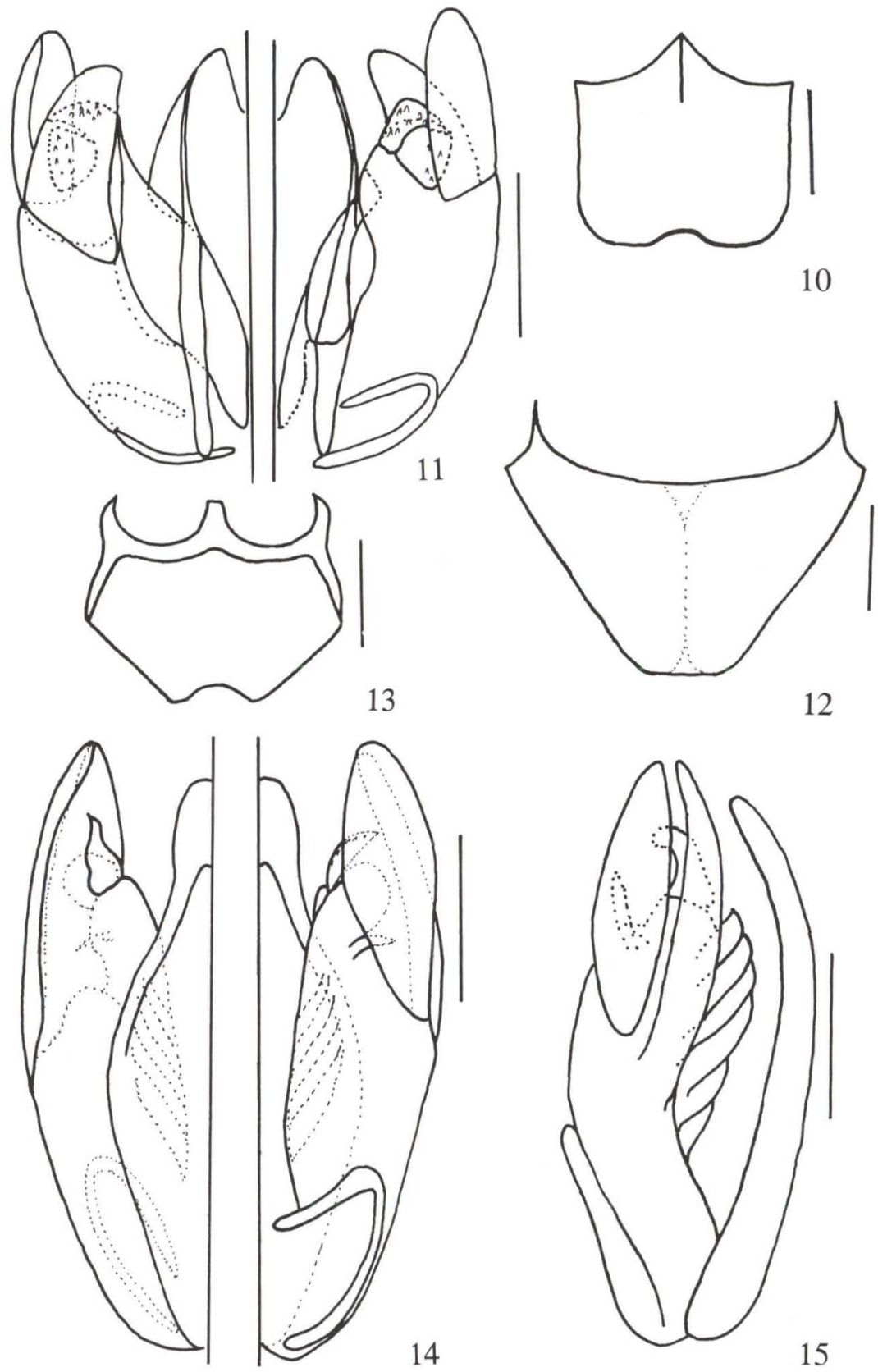

12

10

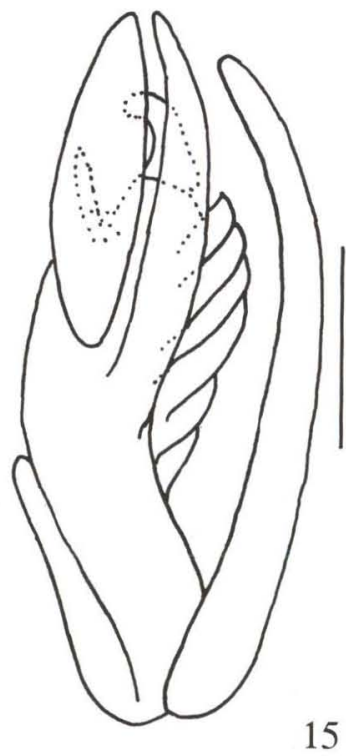

Figs 10-15. (10-11) Lytopsenella herbsti, male: (10) hypopygium, dorsal; (11) genitalia, left dorsal and right ventral. (12-15) Pseudisobrachium erythrocephalum: (12) epypygium, dorsal; (13) hypopygium, dorsal; (14) genitalia, left dorsal and right ventral; (15) genitalia, lateral. Scale bars $=0.1 \mu \mathrm{m}$. 
as thick, scape wide, $0.5 \mathrm{X}$ as thick as long. Frons somewhat weakly coriaceous, punctures very small and shallow, separated by 2-4 X their diameters. Eye short and sparse-haired. LH 1.0 X WH; WF 0.54 X WH; eye large, WF $1.14 \mathrm{X} \mathrm{HE;} \mathrm{frontal}$ angle of ocellar triangle obtuse; posterior ocelli distant from the vertex crest $0.5 \mathrm{X}$ DAO; OOL 1.37 X WOT; head not large behind the eye top, VOL only $0.36 \mathrm{X} \mathrm{HE}$ (Fig. 8). Vertex slightly convex with broadly rounded corners. Temples slightly divergent anteriorly.

Mesosoma (Fig. 7). Thorax weakly coriaceous as frons, punctures small and shallow, separated by $2-5 \mathrm{X}$ their diameters. Pronotal disc with anterior corners angulate. Notauli well-defined, nearly straight, missing in the anterior third of the mesoscutum. Parapsidal furrows very weak and shallow, missing in the anterior third of the mesoscutum. Scutellar pits small, inclined, elliptical and very distant each other. Propodeal disc $1.18 \mathrm{X}$ as wide as long, with an anterior stub of median carina and with a pair of anterior stub of discal carinae, stronger than the median one, without other carinae, propodeum wholly alveolate; declivity without median carina. Mesopleuron with a rounded and deep central pit.

Gaster. Polished, transversal section elliptical, slightly longer than mesosoma. Hypopygium (Fig. 10) long, anterior margin without lateral teeth, only with the median stalk, posterior margin straight with a wide and short median invagination.

Genitalia (Fig. 11). Paramere completely double, both laminas with rounded apex, the ventral slightly inward and the latero-dorsal wider; volsella long-haired in the base, with cuspis very wide, mainly basally, so that it becomes triangular in ventral view, with some denticles in the outer surface, digitus wide with a lot of denticles in the dorsal surface; aedeagus stout, bottle-shaped, wider medially, with apex rounded with a median invagination; basal ring with a pair of dorsal expansion; apodema extending beyond the elliptical basal ring.

Material examined. Holotype female - CHILE, Concepción, (MCZH). New material: 20 females, 4 males CHILE; 6 females Arauco, Pichinahuel, Cord. Nahuelbuta; XI.1958-I.1959; L.E. Peña leg. (CNCI, MNNC); 2 females Talca, Canelillos (E. Carrizal); 3.XI.1991; M. Elgueta leg. (MNNC); 1 female Cauquenes, Pelluhue (S. Chanco); 5.XI.1991; M. Elgueta leg. (MNNC); 1 female Petorca, La Canela (E. Longotoa); 29.X.1991; M. Elgueta leg. (MNNC); 1 female Cardenal Car, Tanumé (N. Pichilemu); 2.XI.1991; M. Elgueta leg. (MNNC); 1 female Ñuble, Bulnes; 13.XII.1991; M. Elgueta col (MNNC); 1 female Concepción, La Florida, 13.XII.1991; M. Elgueta leg. (MNNC); 1 female Concepción, Collico Norte; 13.XII.1991; C. Muñoz leg. (MNNC); 1 female Valdivia, Chauquén (S. Panguipulli); 18.I.1992; M. Elgueta leg. (MNNC); 1 female Valparaiso, km 7 NE. Papudo; 8.VIII.1968; L. \& C.W. O’Brien leg. (AMNH); 1 female Malleco, Cabreria, 1100 m, Cord. Nahuelbuta; 9-15.I.1977; L. E. Peña leg. (CNCI); 1 female Las Cruces, C. Parral, Linares; X.1958; L.E. Peña leg. (CNCI); 1 female Mariluan, 200 m, W. Victoria; 30-31.XII.1976; L.E. Peña leg. (CNCI); 2 males Choapa, km 272 Panam. Norte; 19.XI-17.XII.1985; M. Elgueta leg. (MNNC); 1 male Cautin, 15 km NE, Villarrica, Flordel Lago; 14.XII.1984-10.II.1985; S. \& J. Peck leg. (MNNC); Linares, La Vega (6 km S Parral); M. Elgueta leg. (MNNC). 
Variation. Antenna, palpi and legs wholly light castaneous, mandible nearly white, median carina of the clypeus higher; LH 1.05-1.1 X WH; WF 0.55 X WH; WF 1.09-1.1 X HE; OOL 1.23-1.3 X WOT; frontal angle of the ocellar triangle more obtuse; frons with a linear depression in frons of the anterior ocellus and behind the frontal carina; notauli longer anteriorly or complete; parapsidal furrows can be nearly complete, but almost imperceptible, stronger in one specimen.

Remarks. The sex dimorphism in this species is weak, the lateral margin of the pronotal disc is more divergent behind in females (Fig. 4) than in males (Fig. 7). The most peculiar character in male genitalia is the double paramere. There is a ventral pair completely divided of the lateral pair. There are some species of different genera in Bethylidae with invaginated paramere, but here, there really are two pairs of parameres.

\section{Pseudisobrachium erythrocephalum Evans, 1973}

Figs 12-15

Pseudisobrachium erythrocephalum Evans, 1973: 197-198. - Sarazin, 1986: 295. - Gordh \& Moczar, 1990: 252

This species, endemic to Chile, was known only from the type series, it is characterized by having the reddish or orange head. The median lobe of clypeus can be more invaginated medially than the type. WH 0.94-0.95 X LH; WF 0.7-0.73 X WH; WF 1.87-2.06 X HE; OOL 1.6-2.0 X WOT. Epypygium (Fig. 12) very wide, ventral sides touching each other, anterior margin with a pair of lateral stalks. Hypopygium (Fig. 13) with three basal stalks, the median with the apex blunt, 0.23 $\mathrm{X}$ the hypopygium, the lateral ones with apex sharpened, $1.6 \mathrm{X}$ the median and 0.71 $\mathrm{X}$ their own root, lateral stalk placed at the lateral margin; posterior margin very convergent, and concave in the median third. Genitalia (Figs 14, 15): paramere deeply divided in ventral and dorsal arms, the ventral one broad with rounded apex, inner margin excavated basally, dorsal one thin with rounded apex; volsella with a very wide cuspis, with several inclined marks and with a long sharpened basal tooth, digitus very wide with several teeth in the dorsal surface, vannus with six inclined marks; aedeagus bottle-shaped, apex rounded without invagination, wider in the median third; basal ring V-shaped and completely downward.

Material examined. 1 male CHILE, Malleco, La Fusta (holotype, CNCI). New material: 4 males CHILE, 1 male Ñuble, Las Trancas; 15-18.II.1959; L.E. Peña leg. (CNCI); 1 male Quilotta, Olmue, La Campana, NP, 900m; 2.XII.1984-21.II.1985; S. \& J. Peck leg. (CNCI); 1 male, Valdivia, Lingueto; 15.I.1992; M. Elgueta leg. (MNNC); 1 male Valdivia, Fundo El Molino; 9.IV.1982; D. Jackson leg. (MNNC).

\section{Bethylopsis Fouts, 1939}

The precise taxonomic place of this genus has long been unknown (GORDH \& MOCZAR 1990; TERAYAMA 1995). TERAYAMA (1995) in a phylogenetic approach considered this genus as a member of the tribe Sclerodermini and also similar to Allobethylus Kieffer, 1905, due to general appearance, but this genus has short forewing and notauli absent. Both genera have long and rectangular head, which is 
peculiar in this tribe; besides their distributions can be considered associated to each other, A. multicolor Kieffer, 1905 is from Papua New Guinea and B. fullawayi Fouts, 1939 is from Marquesas Islands. Bethylopsis is recorded for the first time to Neotropical region. This distribution emphasizes the association between Chilean and Australian bethylid fauna.

\section{Bethylopsis carinatus sp.n.}

Figs 16-17

Description of holotype female. Length of body 2,91 mm; LFW 1,12 mm.

Color. Head and mesosoma black; gaster dark castaneous; apical half of mandible, antenna, legs castaneous; wings hyaline, stigma and veins dark castaneous.

Head (Fig. 16). Mandible with four apical teeth, sharpened, progressively larger downward (Fig. 17). Clypeus evenly rounded, with a median elevation, not forming a carina. First four antennal segments in a ratio of about $4: 2: 1: 1$; segment three slightly longer than wide. Frons weakly coriaceous, with punctures minute, very distant each other; frons with a very shallow median groove in the anterior half. WH $0.85 \mathrm{X} \mathrm{LH}$; WF $0.6 \mathrm{X}$ WH; WF $1.33 \mathrm{X} \mathrm{HE}$; eye small and removed from posterior margin of head by $1.53 \mathrm{X}$ HE; ocellar triangle very compact, OOL 2.75 $\mathrm{X}$ WOT; frontal angle of ocellar triangle acute; posterior ocelli distant from vertex crest $3 \mathrm{X}$ their own diameter. Sides of the head parallel. Vertex barely convex with rounded corners.

Mesosoma (Fig. 16). Thorax coriaceous and punctated as frons. Pronotal disc without anterior carina. Mesoscutum without notauli, parapsidal furrows weak, present only in the posterior half of mesoscutum. Scutellar groove conspicuous, thinner medially. Mesopleuron with a rounded, small and deep upper pit. Propodeal disc $1.47 \mathrm{X}$ as wide as long, with a median carina incomplete behind, median area of disc areolate, lateral of propodeum and declivity coriaceous. Forewing short, barely reaching the tergite III of the gaster, stigma subtriangular, transverse-median vein angulate, without metacarpo. Forefemur $2.33 \mathrm{X}$ as long as thick.

Gaster. Stout; weakly coriaceous; transversal section subcircular. Gaster long, $1.75 \mathrm{X}$ mesosoma.

Material examined. Holotype female - CHILE, Choapa km 272; Panam, Norte, ex. Ademia microphylla; 24.IX.1985; M. Elgueta leg. (MNNC); 1 paratype female CHILE, Quilota, Olmue, La Campana, NP; 2.XII.1984-21.II.1985; S. \& J. Peck leg. (CNCI).

Variation. Gaster castaneous at the posterior margin of tergite I-III; ocellar triangle slightly broader; parapsidal furrows stronger and longer; forewing conspicuously longer, reaching the tergite IV; propodeal disc 1.33 as wide as long.

Remarks. This species has notauli absent and short forewing, but not so much as in Bethylopsis fullawayi. It is recognized by tetradentate mandible, stigma subtriangular, transverse-median vein angulate, scutellar groove conspicuous and the median groove in the frons.

Etymology. Name referring to the median carina of the propodeal disc. 

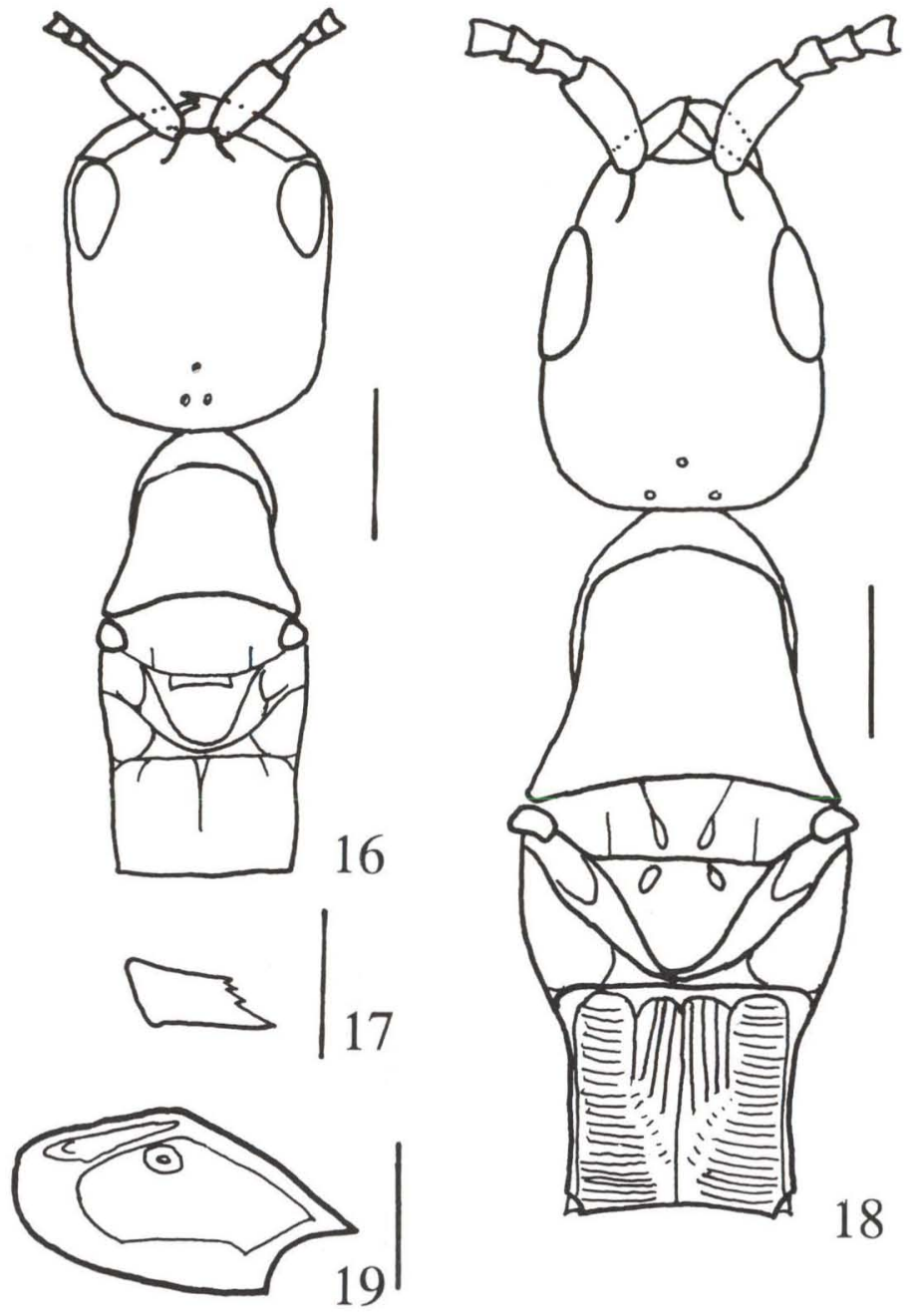

Figs 16-19. (16-17) Bethylopsis carinatus sp.n.: (16) head and mesosoma, dorsal, (17) mandible, frontal; (18-19) Epyris chilensis sp.n.: (18) head and mesosoma, dorsal; (19) mesopleuron, lateral. Scale bars $=0.3 \mathrm{~mm}$.

Epyris chilensis sp.n.

Figs $18-19$

Description of holotype female. Length of body 3,99 mm; LFW 2,16 mm.

Colors. Black; antennae, mandibles, legs dark castaneous; tegula castaneous; wings subhyaline, veins and stigma castaneous.

Head (Fig. 18). Mandible five-teethed, the lower large and sharpened, the 
four upper very small and rounded in a oblique series. Clypeus with median lobe developed, narrowly rounded, median carina straight in profile, clypeus in an inferior plan to frons. First four antennal segments in a ratio of 7:2:2:3; segment three slightly thicker than long. Eye sparsely long-haired. Frons weakly coriaceous, with punctures small, shallow, separated $3 \mathrm{X}$ their own diameter; frons with a shallow median groove in the anterior fourth, wider behind. WH $0.87 \mathrm{X} \mathrm{LH}$; WF $0.67 \mathrm{X} \mathrm{WH}$; WF $1.5 \mathrm{X} \mathrm{HE}$; distance from eye tops to vertex crest $0,8 \mathrm{X} \mathrm{HE}$; OOL $1.63 \mathrm{X}$ WOT; frontal angle of ocellar triangle slightly acute; posterior ocelli distant from vertex $1.0 \mathrm{X}$ their own diameters. Vertex straight with corners rounded. Temples parallel.

Mesosoma (Fig. 18). Thorax coriaceous and punctated as frons. Pronotal disc $1.17 \mathrm{X}$ as wide as long. Mesoscutum short, $3 \mathrm{X}$ shorter than pronotal disc, depressed transversally. Notauli complete, thin and divergent anteriorly. Parapsidal furrows incomplete and divergent anteriorly, barely wider than notauli. Scutellar pits elliptical and inclined, separated by $1.67 \mathrm{X}$ their own length. Propodeal disc 1.12 as wide as long, median area not sharply defined, except anterior fourth, median carina complete, median area with undefined discal carinae with longitudinal cross-ridges; sides of disc transversally weakly striate; posterior angles with a small fovea; lateral of propodeum imbricate; declivity of propodeum imbricate with a median carina complete. Mesopleuron (Fig. 19) with a very broad fovea fully outlined, except at the anterior corner, with a small rounded pit. Forefemur $2 \mathrm{X}$ as long as thick. Midtibia spinose.

Gaster. Polished, transversal section elliptical.

Material examined. Holotype female-CHILE, Santiago, est. Exp. La Platina; 7.XI.1990; M. Elgueta leg. (MNNC); 2 paratypes females CHILE, Santiago, Maipu (Cuidad); 10.XII.1986 and 13.II.1990; M. Elgueta leg. (MNNC).

Remarks. This species is the first of Epyris known from Chile. It is similar to E. myrmecophilus (Brues, 1903), but the vertex of E. chilensis sp.n., is straight medially, the median area of propodeal disc is not sharply margined and the midtibia is with some spines instead of E. myrmecophilus with the vertex rounded medially, the median area of propodeal disc sharply margined and the midtibia strongly spinose. It also is similar to E. californicus (Ashmead, 1893), but mesopleuron fovea of $E$. chilensis sp.n., is not fully outlined anteriorly, the mesoscutum is short and the temples is parallel instead of E. californicus with mesopleuron fovea not fully outlined dorsally, long mesoscutum and the temples diverging anteriorly.

Etymology. Name referring to country of type-locality.

\section{Chilepyris herbsti Evans, 1964}

Chilepyris herbsti Evans, 1964: 167-168. - Sorg \& Walker 1988: 1486-1468. - Gordh \& Moczar, 1990: 82.

This species was known only from the type, the second one similar to the type are analyzed, as follows: WH 1.1 X LH; WF 0.64 X WH; WF 1.62 X HE; OOL $2.6 \mathrm{X}$ WOT; distance from the eye tops to vertex crest $0.93 \mathrm{X} \mathrm{HE}$; parapsidal furrows complete; propodeal disc 1.8 as long as wide; forefemur 2.3 as long as thick. 
Material examined. Holotype female CHILE, Baños de Cauquenes (MCZH). New material: 1 female CHILE, Santiago, Rio Colorado; 13.XII.1970; L. Alfaro leg. (MNNC).

ACKNOWLEDGMENT. To C.R.F. Brandão (MZSP) and E.R. Bortolini (UFES) to the loan of camera lucida, to curators cited in the text by the loan of the material studied and to J. LaSalle (IIE, London) who reviewed the manuscript.

\section{REFERENCES}

Evans, H.E. 1964. A synopsis of the American Bethylidae (Hymenoptera, Aculeata). Bull. Mus. Comp. Zool. 132 (1): 1-222.

1967. New generic records of Bethylidae from South American. Proc. Entomol. Soc. Wash. 69 (3): 269-272.

. 1969a. The genus Pseudisobrachium in Argentina and Chile. Acta Zool. Lilloana 25 (5): 45-65.

. 1969b. The genera Apenesia and Dissomphalus in Argentina and Chile (Hymeneoptera, Bethylidae). Breviora 311: 1-23.

. 1973. Further studies on South American Bethylidae (Hymenoptera).

Proc. Entomol. Soc. Wash. 75 (2): 194-204.

GoRDH, G. \& L. MOCZAR. 1990. A catalog of the world Bethylidae (Hymenoptera).

Mem. Amer. Entomol. Inst. 46: 1-364.

Harris, R.A. 1979. A glossary of surface sculpturing. Occ. Pap. Entomol. 28: $1-31$.

KIEFFER, J.J. 1904. Description d'un nouveaux genre et de nouvelles espèces de Proctotrypides du Chili. Rev. Chil. Hist. Nat. 8: 142-146.

- 1908. Bethylidae. Genera Insectorum 76: 1-50.

. 1910. Description de nouveaux béthylides (Hyménoptères). Ann. Soc. Entomol. France 79: 31-56.

1911. Nouveaux béthylides et dryinides exotiques du British Museum de

Londres. Ann. Soc. Scientif. Bruxelles 35: 200-233.

1914. Bethylidae. Das Tierreich 41: 1-595.

Ogloblin, A. 1953. Los insectos de las Islas Juan Fernandez. 14. Bethylidae y

Dryinidae (Hymenoptera). Rev. Chil. Entomol. 3: 101-115.

Perez D'A., V. 1981. El genero Pseudisobrachium Kieffer en Chile (Hymenoptera, Bethylidae, Pristocerinae). Rev. Chil. Entomol. 10: 61-62.

PolaszeK, A. \& K.V. KROMBeIN. 1994. The genera of Bethylinae (Hymenoptera,

Bethylidae). Jour. Hymenop. Res. 3 (1): 91-105.

SARAZIN, M.J. 1986. Primary types of Aculeata (Hymenoptera) in the Canadian

National Collection. Canadian Entomologist 118 (4): 287-318.

SORG, M. \& A.K. WALKER. 1988. A new species of bethylid wasp (Hymenoptera)

from New Zeland, with comments on its life history and host. Jour. Nat. Hist.

22 (6): 1483-1488.

Terayama, M. 1995. The phylogeny of the Bethylidae wasps tribe Scerodermini

(Hymenoptera, Bethylidae). Proc. Japan. Soc. Syst. Zool. 54: 65-73. 